\title{
Efficacy of benznidazol treatment for asymptomatic chagasic patients from state of Rio Grande do Sul evaluated during a three years follow-up
}

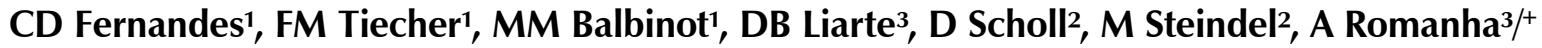 \\ ${ }^{1}$ Instituto de Pesquisa Biológica, Laboratório Central, Fundação Estadual de Produção e Pesquisa em Saúde, Porto Alegre, RS, Brasil \\ ${ }^{2}$ Departamento de Microbiologia e Parasitologia, CCB, Universidade Federal de Santa Catarina, Florianópolis, SC, Brasil \\ ${ }^{3}$ Instituto de Pesquisa René Rachou-Fiocruz, Belo Horizonte, MG, Brasil
}

The efficacy of benznidazol on the treatment of chagasic patients from the state of Rio Grande do Sul was evaluated during a three-year follow-up. A cohort of 80 asymptomatic chronic chagasic patients or blood bank donors (49 male and 31 female) was studied. Their ages varied from 17-42 years, with a mean and a median of 30 and 35 years, respectively. The 80 patients presented positive serology, hemoculture and polymerase chain reaction (PCR). They were treated with $5 \mathrm{mg} / \mathrm{Kg}$ benznidazol twice a day for 60 days. Serological, parasitological and PCR methods were used to evaluate response. Serology was performed using commercial ELISA and indirect immunofluorescence (IFI) tests, parasitemia was monitored by hemoculture in LIT medium and PCR with primers S35/S36 was used to amplify $a$ Trypanosoma cruzi 330 bp kDNA repetitive sequence. PCR positivity of 240 seropositive individuals was compared using DNA preparations from whole blood/guanidine EDTA (GE), buffy-coat/GE and frozen buffy-coat. Fifty non-chagasic individuals were used as negative controls. PCR positivity was $86.7 \%$ for the frozen buffy-coat, $71.7 \%$ for the GE/buffy-coat and $69.2 \%$ for the GE/whole blood. The hemocultures became negative just after treatment and remained negative during the three years of follow-up. In the third year after treatment, 9/80 (11.3\%) patients presented negative PCR and, from those, four also presented negative serological tests. Furthermore, a reduction in three serological titers was observed in 27/80 (33.8\%) of the patients treated. Taken together, the results show that four of the $80(5.0 \%)$ chronic chagasic patients from the state of Rio Grande do Sul were cured after treatment with benznidazol.

Key words: Chagas disease - diagnosis - polymerase chain reaction - benznidazol treatment - cure

Trypanosoma cruzi, the aetiological agent of Chagas disease, is a hemoflagellate protozoan parasite that affects about 15-16 million individuals and it is estimated that 75-90 million people are exposed to infection in Latin America (Coura 2007). In Brazil, the vector control program, established in 1975 and continuing with the South Cone Initiative, eliminated the main vector, Triatoma infestans, from the country (Massad 2007). The seroprevalence of $T$. cruzi infection in Brazil among children aged 7-14 years fell $99.8 \%$ from 1980-1999 and the absence of seropositivity among young children (aged 0-4 years) is evidence of the interruption of vectorial transmission (Massad 2007). In Brazil, the highest prevalence of $T$. cruzi infection was found in the states of Rio Grande do Sul, Minas Gerais, São Paulo, Paraná, Goiás and Bahia (Silveira \& Rezende 1994, Dias 1997).

Human Chagas disease presents two distinct phases: the acute phase, which appears just after infection, and the chronic phase, which may last several years. After a long asymptomatic phase, around 30\% of infected individuals develop chronic disease with severe damage

Financial support: IPB/LACEN, CNPq, Fiocruz

+ Corresponding author: romanha@cpqrr.fiocruz.br

Received 4 June 2008

Accepted 11 December 2008 to the heart and digestive system (Prata 2001). During the acute phase, $T$. cruzi trypomastigotes are usually detected by microscopic examination of fresh or stained blood-smears, as well as by xenodiagnosis and hemoculture (Luquetti \& Rassi 2000). In contrast, during the chronic phase, diagnosis is based on the detection of circulating antibodies (Luquetti \& Rassi 2000). However, due to the long-lasting maintenance of circulating antibodies, it is difficult to use serology as a marker for cure of the disease even after the successful treatment of $T$. cruzi infection (Luquetti \& Rassi 2000).

PCR comparative studies of whole blood were performed using traditional methods, such as xenodiagnosis and serology, for detecting T. cruzi; these showed that amplification of $T$. cruzi kDNA may substitute for xenodiagnosis in assessing parasitemia in chronic chagasic patients and may also be used as a complement to serological tests in blood banks (Avila et al. 1993, Marcon et al. 2002). Other studies showed that polymerase chain reaction (PCR) is a sensitive method that may detect the parasite DNA in up to $95 \%$ of blood samples from chronic chagasic patients (Britto et al. 1995a, Silber et al. 1997). Furthermore, PCR was shown to be a very useful tool for confirmation of diagnosis in patients with doubtful serology (Marcon et al. 2002).

In this work, we followed up on the serological, parasitological and PCR profiles of 80 asymptomatic chagasic patients treated with benznidazol. In addition, 
considering that PCR sensitivity depends mainly on the target and source of the DNA, we compared different forms of biological sample preservation as sources of T. cruzi kDNA.

\section{PATIENTS, MATERIALS AND METHODS}

Clinical samples and procedures - A cohort of 80 asymptomatic chronic chagasic patients or blood bank donors (49 males and 31 females) from the state of Rio Grande do Sul presenting positive serology and hemoculture was studied. Their ages varied from 17-42 years old, with a mean and median age of 30-35 years, respectively. Patients were treated with $5 \mathrm{mg} / \mathrm{Kg}$ benznidazol twice a day for 60 days. Our cohort was obtained from an initial group of 240 seropositive chagasic individuals. A negative control group, consisting of 50 individuals with negative serology, hemoculture and PCR for T. cru$z i$ infection was included in the study. Chagasic patients were followed annually for a three-year period by serology, hemoculture and PCR.

Blood collection was performed with a Vacutainer ${ }^{\circledR}$ system (Becton Dickinson, Franklin Lakes) based on the following volumes and objectives: i) $10 \mathrm{~mL}$ of blood for serology, ii) $30 \mathrm{~mL}$ of blood with heparin for hemoculture and iii) $15 \mathrm{~mL}$ of blood in EDTA $\mathrm{Na}_{2}$ for PCR. Five milliliters of whole blood was mixed $(\mathrm{v} / \mathrm{v})$ with $6 \mathrm{M}$ guanidine hydrochloride/0.2M EDTA buffer $\mathrm{pH} 8.0$ (GE buffer) immediately after collection and was stored at $4^{\circ} \mathrm{C}$ until use. For the remaining $10 \mathrm{~mL}$ of whole blood, the buffy-coat was separated by centrifugation in a histopaque gradient ${ }^{\mathbb{R}}$ (Sigma, St. Louis), collected and divided into two tubes; one was stored at $-70^{\circ} \mathrm{C}$ and the other was added to $250 \mu \mathrm{L}$ of $\mathrm{GE}$ buffer and stored at $4^{\circ} \mathrm{C}$ until use.

Serological assays - The enzyme-linked immunosorbent assay (ELISA) was performed using the commercial Chagatest-Wienner kit (ELISA recombinant $\mathrm{v}$. 3.0). Briefly, sera were diluted $1 / 20$ in phosphate-buffered saline-tween $20(0.05 \%)$ containing $1 \%$ bovine serum albumin. Two hundred microliters of diluted sera was added to microwells containing T. cruzi antigens. The plates were incubated at $37^{\circ} \mathrm{C}$ for $30 \mathrm{~min}$. After five washes in $0.1 \mathrm{M}$ phosphate buffer to remove unbound immunoglobulin, the samples were incubated at $37^{\circ} \mathrm{C}$ for 30 min with a 1:40,000 dilution of peroxidase-labelled anti-human IgG conjugate. After another wash step, the plates were revealed with $60 \mathrm{mM}$ hydrogen peroxide in $50 \mathrm{mM}$ citrate buffer, $\mathrm{pH} 3.2$ and $0.01 \mathrm{mM}$ tetramethylbenzidine in $0.1 \mathrm{~N}$ chloride acid. After $30 \mathrm{~min}$ incubation at $\mathrm{rt}$, the reaction was stopped by the addition of $2 \mathrm{~N}$ sulphuric acid. The plates were read at a wavelength of 450-620 nm in a microplate reader (Anthos Labetec Instruments, Austria). The mean absorbance of the negative controls plus 0.3 OD was used for cut off determination according to the manufacturer's instructions.

Indirect immunofluorescence (IFI) assays were performed using the (IFI)-Chagas Bio Manguinhos Kit, FIOCRUZ, RJ, according to the manufacturer's instructions. Serum dilutions $(1 / 40-1 / 1280)$ in phosphate buffer saline, $\mathrm{pH} 7.2$ (PBS), were incubated for $30 \mathrm{~min}$ at $37^{\circ} \mathrm{C}$ with total antigen pre-adsorbed onto the slide surface.
Unbound immunoglobulins were removed by washing the slides twice with PBS. Following incubation with fluorescein-labeled anti-human IgG conjugate for 30 min at $37^{\circ} \mathrm{C}$, unbound conjugate was removed by two washes with PBS. Slides were mounted with buffered glycerine, $\mathrm{pH}$ 9.5, and observed under a fluorescence microscope (Labophot Nikon, Japan). Positive chagasic and negative sera were used as controls. The cut off value for IFI was $1 / 40$.

Hemoculture - Hemoculture was performed as described by Galvão et al. (1989). Briefly, $30 \mathrm{~mL}$ of heparinized venous blood was collected from each individual in a vacutainer system (Vacuum II) and centrifuged at $600 \mathrm{~g}$ for $30 \mathrm{~min}$ at $4^{\circ} \mathrm{C}$. Plasma was collected and stored at $-20^{\circ} \mathrm{C}$. The pellet was resuspended in $15 \mathrm{~mL}$ of LIT (liver infusion tryptose) medium and centrifuged as described above. After removal of the supernatant, the pellet was resuspended in $30 \mathrm{~mL}$ of LIT and distributed into six tubes $(18 \times 150 \mathrm{~mm})$, which were maintained at $28^{\circ} \mathrm{C}$ and examined monthly until the fourth month. Only patients with positive hemocultures were treated. They received $5 \mathrm{mg} / \mathrm{kg}$ benznidazol twice a day for 60 days, followed by yearly serology, hemoculture and PCR analyses over the three years.

DNA extraction and PCR - The buffy coat was added to $200 \mu \mathrm{L}$ of extraction buffer ( $50 \mathrm{mM}$-Tris $\mathrm{HCl}, \mathrm{pH} 8.0 / 50$ $\mathrm{mM}$ EDTA $/ 100 \mathrm{mM} \mathrm{NaCl} / 0.5 \% \mathrm{SDS}$ ) and incubated with $20 \mu \mathrm{g} / \mathrm{mL}$ proteinase $\mathrm{K}$ (Sigma) for $2 \mathrm{~h}$ at $45^{\circ} \mathrm{C}$. Following a phenol/chloroform extraction and ethanol/3M sodium acetate precipitation, the DNA was washed twice with $70 \%$ ethanol, resuspended in $50 \mu \mathrm{L}$ of TE buffer (Tris-

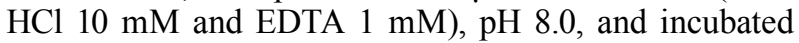
with RNAse A $(10 \mu \mathrm{g} / \mathrm{mL})$ at $42^{\circ} \mathrm{C}$ for $1 \mathrm{~h}$. Blood lysates were boiled for $15 \mathrm{~min}$ for kDNA decatenation (Britto et al. 1993) and a $0.5 \mathrm{~mL}$ sample was subjected to phenol/ chloroform extraction as already described.

Primers S-35 (5' -AAA TAA TGT ACG GGT GAG ATG CAT GA-3') and S-36 (5' -GGG TTC GAT TGG GGT TGG TGT-3') (Sturm et al. 1989) were used to amplify a $330 \mathrm{bp}$ fragment corresponding to the $T$. cruzi minicircle. Amplification reactions were performed in a final volume of $10 \mu \mathrm{L}$ containing $1 \mathrm{U}$ Taq DNA polymerase (Biotools), $200 \mu \mathrm{M}$ of each dNTP, $1.5 \mathrm{mM} \mathrm{MgCl}_{2}$, and $10 \mathrm{mM}$ Tris-EDTA, $\mathrm{pH} 9.5,5$ pmoles of each primer and $2 \mu \mathrm{L}$ of DNA preparation diluted 1/10 in TE buffer. DNA amplification was carried out in an Eppendorf Mastercycler using the following temperature profile: an initial step at $95^{\circ} \mathrm{C} /$ for $5 \mathrm{~min}$, followed by 34 cycles at $95^{\circ} \mathrm{C} / 1$ $\min , 60^{\circ} \mathrm{C} / 1 \mathrm{~min}$ and $72^{\circ} \mathrm{C} / 1 \mathrm{~min}$, and a final extension step at $72^{\circ} \mathrm{C} / 5 \mathrm{~min}$. Positive controls consisted of $10 \mathrm{pg}$ of T. cruzi DNA (Y strain) and $2 \mu \mathrm{L}$ of an artificial mixture of human $+T$. cruzi DNA (diluted 1:10). Negative controls consisted of $2 \mu \mathrm{L}$ of non-chagasic human DNA (diluted 1:10). The amplified products were subjected to $1.5 \%$ agarose gel electrophoresis, visualized under UV light after ethidium bromide staining and digitally recorded in a Digidoc-it UVP ${ }^{\circledR}$ system (Cambridge, England). Forward HuHGPRT1 (5' ATGGCGACCCGCAGCCCTGG 3') and HuHGPRT2 reverse (5' GAATGGATCTATCACTATTT 3') primers were used to ampli- 
fy a 280 pb DNA fragment corresponding to the human gene sequence \# gil64518913. The thermal conditions and reagent concentrations were the same as above except that the number of cycles was 30 and DNA preparation dilution was 1:100.

Ethics - Informed written consent was obtained from all individuals enrolled in this study. This work was approved by the Ethical Committee IPB/LACEN/FEPPS (protocol n. 05/2003) and fulfills resolution number 196/1996 from the Brazilian National Health Council for research involving human beings.

\section{RESULTS}

From the initial cohort of 240 seropositive asymptomatic chagasic patients, $57.5 \%$ were male and $42.5 \%$ were female with ages ranging from 17-53 years old (mean age 38 years). Anti-T. cruzi IgG antibodies were confirmed by both ELISA and IFI tests. Antibody titration by IFI varied from 1/40-1/640. A serological titer of $1 / 40$ was found in $27.5 \%, 1 / 80$ in $20.0 \%, 1 / 160$ in $23.3 \%$, $1 / 320$ in $12.1 \%$ and $1 / 640$ in $17.1 \%$ of patients, respectively. From those, a group of 80 individuals, 49 men and 31 women with positive serology, hemoculture and PCR, aged 17-42 years with a mean of 30 years and a median of 35 years, received treatment with benznidazol. They were followed annually by serology for a period of three years (Table I). At the third year after treatment, a decrease of three, two and one, titer in the IFI test was observed in 27 (33.8\%), $33(41.2 \%)$ and 12 (15.0\%) patients, respectively. Four $(5.0 \%)$ patients remained with the same title and four (5\%) became negative (data not shown). The last four patients (one in the 2 nd year and three in the 3rd) presented negative serology by both IFI and ELISA tests, showing evidence of being cured. The hemocultures became negative after treatment and remained negative throughout the three years of follow-up. As little as $0.1 \mathrm{fg}$ of pure $T$. cruzi DNA could be detected by PCR. In artificial mixtures, T. cruzi k-DNA was specifically detected even in the presence of an excess

\section{TABLE I}

Indirect immunofluorescence titers for the follow-up of 80 chagasic patients from the state of Rio Grande do Sul following treatment with benznidazol

\begin{tabular}{lcrcc}
\hline & & \multicolumn{3}{c}{ After treatment } \\
\cline { 3 - 5 } & $\begin{array}{c}\text { Before } \\
\text { treatment }\end{array}$ & 1st year & 2nd year & 3rd year \\
\hline Serology titer & $\mathrm{n}$ & $\mathrm{n}$ & $\mathrm{n}$ & $\mathrm{n}$ \\
\hline Negative & 0 & 0 & 1 & 4 \\
$1 / 40$ & 6 & 6 & 10 & 39 \\
$1 / 80$ & 6 & 15 & 38 & 35 \\
$1 / 160$ & 30 & 33 & 24 & 2 \\
$1 / 320$ & 14 & 24 & 7 & 0 \\
$1 / 640$ & 24 & 2 & 0 & 0 \\
\hline Total & 80 & 80 & 80 & 80 \\
\hline
\end{tabular}

of $10^{6}$-fold human DNA. Pre-treatment PCR positivity for $T$. cruzi k-DNA detection in blood by using different methods for preserving biological samples is shown in Table II. The results show that preservation of buffy coat at $-70^{\circ} \mathrm{C}$ provides the highest PCR positivity $(86.7 \%)$. All 50 individuals used as negative controls were PCR negative. A comparison between serology and PCR results from the 80 patients treated with benznidazol after three years of follow-up is shown in Table III. In the third year after treatment, nine patients with positive PCR before treatment presented negative PCR and, from those, four presented negative serology as well. All the patients who were PCR-negative for T. cruzi DNA presented the specific band (280 bp) for the human hypoxanthine phosphorybosil transferase (HGPRT) gene, excluding the possibility of PCR reaction inhibition.

\section{TABLE II}

Pre-treatment PCR positivity for T. cruzi k-DNA detection in blood by using different methods for preserving biological samples

\begin{tabular}{lc}
\hline Source of $T$. cruzi DNA & $\begin{array}{c}\text { PCR positivity (\%) } \\
(\mathrm{n}=240)\end{array}$ \\
\hline Buffy-coat $-70^{\circ} \mathrm{C}$ & $208 / 240(86.7)^{a}$ \\
Buffy-coat GE buffer & $172 / 240(71.7)$ \\
Whole blood GE buffer & $156 / 240(69.2)$ \\
\hline
\end{tabular}

$a: \mathrm{p}<0.05$, Chi square test; GE: guanidine/EDTA.

\section{TABLE III}

Comparison between serology and PCR results from the 80 patients treated with benznidazol after a three-years follow-up

\begin{tabular}{lcc}
\hline Methodology & Positive (\%) & Negative (\%) \\
\hline Serology & $76(95.0)$ & $4(5.0)$ \\
PCR & $71(88.3)$ & $9(11.3)$ \\
\hline
\end{tabular}

\section{DISCUSSION}

Different tools have been used to diagnose chronic T. cruzi infection. Most of the serological commercial kits are highly sensitive for the detection of anti-T. cruzi antibodies, but in Latin American countries where other parasites such as Leishmania spp. and Trypanosoma rangeli are found, false-positive results have been reported (Saldaña \& Sousa 1996, Caballero et al. 2007). In the state of Rio Grande do Sul, asymptomatic infection by Leishmania Viannia parasites in humans has been recently reported (Fagundes et al. 2007).

In the present study, 240 chronic chagasic patients with an indeterminate form of Chagas disease were evaluated by serology, hemoculture and PCR methods. According to the WHO proposal, at least two distinct tests should be performed for a final serodiagnosis conclusion. In our study, $100 \%$ concordance between 
IFI and ELISA assays was found. However, distinct antibody titers varying from $1 / 40-1 / 640$ were found among these patients. It is well established that the $T$. cruzi taxon presents two major lineages (TcI and TcII) that may influence parasite antigenic composition and, consequently, patient antibody responses (Di Noia et al. 2002, Buscaglia \& Di Noia 2003). This fact must be considered when low or borderline antibody titers are found since most of the commercial kits use the T. cruzi TcII lineage as the antigen. Gutierrez et al. (2004) compared four different serological tests and reported discordant results for 15 out of 94 sera from Colombian chagasic patients. According to the authors, an in-house ELISA using an autochthonous T. cruzi TcI as the antigen shows the highest sensitivity, probably due to the fact that the TcI genotype is the most prevalent in that region. The TcII lineage is found most frequently in both acute and chronic chagasic patients in the south cone countries (Miles et al. 1980, Yeo et al. 2005, Steindel et al. 2008). In Brazil, distinct zymodemes are associated with acute and chronic Chagas disease (Luquetti et al. 1986).

The state of Rio Grande do Sul showed one of the highest prevalence rates $(8.84 \%)$ of $T$. cruzi infection in humans (Camargo et al. 1984). Despite this high infection prevalence, it is noteworthy that manifestations of cardiac or digestive disease are rare in the state of Rio Grande do Sul (Vinhaes \& Dias 2000). It has been speculated that this apparent difference may be due to the characteristics of the $T$. cruzi populations circulating there. In the southern cone regions where the TcII genotype is most frequently found in humans, chagasic mega syndromes are common. In comparison, they are absent in the North of the Amazon (Miles et al. 1981). It seems that the TcII genotype is more virulent than TcI (Di Noia et al. 2002). Studies of 29 T. cruzi strains isolated from chagasic patients from the state of Rio Grande do Sul showed that these strains exhibit low virulence patterns in mice (Fernandes et al. 1997).

According to the Brazilian Ministry of Health, treatment of T. cruzi infection is recommended during the acute phase, congenital infection, early chronic phase (children under 15 years old and elderly patients with evidence of early chronic infection) and reactivation of the infection in individuals infected with HIV. At the Centro de Cardiologia do Rio Grande do Sul, specific treatment for $T$. cruzi infection is offered to all patients having a positive hemoculture. In the present study, 80 patients with positive hemoculture received treatment with benznidazol $(5 \mathrm{mg} / \mathrm{kg}$ of body weight for 60 days taken twice a day) and were followed up for a three-year period by means of serological, parasitological and PCR methods.

Differences in the sensitivity of hemoculture have been reported. Luz et al. (1993) found 90\% positivity among untreated chronic chagasic patients from the state of Minas Gerais. Fernandes et al. (1999) reported $76 \%$ positivity among children from the state of Rio Grande do Sul. Lower rates of sensitivity for chronic patients have been shown by other authors (Chiari et al. $1989,55.8 \%$, Gomes et al. $1999,36.5 \%$, Lages-Silva et al. 2006, 53.0\%). Such differences may represent distinct levels of parasitemia that may depend on the phase of the disease, the parasite strain and the host immune response. In the present study, 80/240 (33.3\%) positivity by hemoculture was found in the chronic chagasic patients with positive serology.

Longitudinal studies in endemic and non-endemic areas have shown that anti-T. cruzi antibodies persisted in infected individuals for many years (Coura et al. 1996, Gomes et al. 1999, Francolino et al. 2003). On the other hand, serology became negative after successful parasitological treatment of both acute and chronic infection, indicating cure from the infection (Luquetti 1999). A negative parasitological test alone does not represent treatment success; however, its positivity after chemotherapy represents therapeutic failure. In a study of 27 chronic chagasic patients from the state of Goiás submitted to chemotherapy with benznidazol, $11.1 \%$ of the patients presented positive hemoculture, demonstrating treatment failure (de Castro et al. 2006). In the present study, none of the 80 treated patients showed positive hemocultures in the three-year follow-up. Seventy-six out of the $80(95.0 \%)$ patients showed positive serology with decreasing titers during the follow-up and four patients $(5.0 \%)$ revealed negative serology by both methods - evidence of being cured. One of those patients negated the serology in the second year after treatment and the other three negated the serology in the third year.

Due to the long persistence of anti-T.cruzi antibodies after chemotherapy and the low sensitivity of parasitological methods, PCR has been suggested to be a very useful tool for treated patients' follow-up (Britto et al. 1995b). In our study, we analyzed the performance of PCR for the detection of $T$. cruzi k-DNA in the blood of two panels of patients using three distinct sample preservation methods. PCR performed with the frozen buffy coat as the $T$. cruzi DNA source showed a higher positivity than the GE-preserved buffy coat or whole blood. The higher PCR positivity on buffy coat preparations is due to similar density between leucocytes and $T$. cruzi. Therefore, the bloodstream parasites concentrate on that zone after differential centrifugation. It is well known that hemoglobin is a strong PCR inhibitor. In our experiments using primers for the detection of the human HGPRT gene, we observed the expected band in all PCR-negative patients, revealing that the PCR reaction was not inhibited.

The interpretation of the PCR results in the diagnosis of Chagas disease is controversial since a positive result may reflect the detection of the DNA of either an intact or a lysed parasite (Britto et al. 1995b, 2001). During the recent outbreak of Chagas disease in the state of Santa Catarina, $100 \%$ PCR positivity was found among the 18 patients evaluated (Steindel et al. 2008). In the present study, nine out of the $80(11.3 \%)$ patients negated the PCR three years after treatment with benznidazol. Considering that antibody titers can be detected for several years, the negative PCR results suggest the process of healing. One may speculate that these patients will be the next to be cured. Taken together, our results suggest that four out of the 80 asymptomatic chagasic patients submitted for chemotherapy with benznidazol were cured of the infection after a three-year follow-up. 


\section{REFERENCES}

Avila HA, Pereira JB, Thiemann O, de Paiva E, De Grave W, Morel CM, Simpson L 1993. Detection of Trypanosoma cruzi in blood specimens of chronic chagasic patients by polymerase chain reaction amplification of kinetoplast minicircle DNA: comparison with serology and xenodiagnosis. J Clin Microbiol 31: 2421-2426.

Britto C, Cardoso A, Silveira C, Macedo V, Fernandes O 1995a. Polymerase chain reaction (PCR) as a laboratory tool for the evaluation of the parasitological cure in Chagas disease after specific treatment. Medicina (B Aires) 59: 176-178.

Britto C, Cardoso MA, Vanni CM, Hasslocher-Moreno A, Xavier SS, Oelemann W, Santoro A, Pirmez C, Morel CM, Wincker P 1995b. Polymerase chain reaction detection of Trypanosoma cruzi in human blood samples as a tool for diagnosis and treatment evaluation. Parasitology 110: 241-247.

Britto C, Cardoso MA, Winker P, Morel CM 1993. A simple protocol for the physical cleavage of Trypanosoma cruzi kinetoplast DNA present in blood samples and its used in polimerase chain reaction (PCR) based diagnosis of Chagas disease. Mem Inst Oswaldo Cruz 88: 1711-1712.

Britto C, Silveira C, Cardoso MA, Marques P, Luquetti A, Macêdo $\mathrm{V}$, Fernandes O 2001. Parasite persistence in treated chagasic patients revealed by xenodiagnosis and polymerase chain reaction. Mem Inst Oswaldo Cruz 96: 823-826.

Buscaglia CA, Di Noia J 2003. Trypanosoma cruzi clonal diversity and the epidemiology of Chagas' disease. Microb Infec 5: 419-427.

Caballero ZC, Sousa OE, Marques WP, Saez-Alquezar A, Umezawa ES 2007. Evaluation of serological tests to identify Trypanosoma cruzi infection in humans and determine cross-reactivity with Trypanosoma rangeli and Leishmania spp. Clin Vaccine Immunol 14: $1045-1049$

Camargo ME, Silva GR, Castilho EA, Silveira AC 1984. Inquérito sorológico da prevalência da infecção chagásica no Brasil, 19751980. Rev Inst Med Trop São Paulo 26: 192-204.

Chiari E, Dias JC, Lana M, Chiari CA 1989. Hemocultures for the parasitological diagnosis of human chronic Chagas' disease. Rev Soc Bras Med Trop 22: 19-23.

Coura JR 2007. Chagas disease: what is known and what is needed - A background article. Mem Inst Oswaldo Cruz 102 (Suppl 1): $113-122$.

Coura JR, Fernandes O, Arboleda M, Barett TV, Carrara N, Degrave W, Campbell DA 1996. Human infection by Trypanosoma rangeli in the Brazilian Amazon. Trans R Soc Trop Med Hyg 90: 278-279.

de Castro AM, Luquetti AO, Rassi A, Chiari E, Galvão LM 2006. Detection of parasitemia profiles by blood culture after treatment of human chronic Trypanosoma cruzi infection. Parasitol Res 99: 379-383.

Di Noia JM, Busgaglia CA, Marchi CR, Almeida IC, Frasch AC 2002. A Trypanosoma cruzi small surface molecule provides the first immunological evidence that Chagas' disease is due to single parasite lineage. J Exp Med 195: 401-413.

Dias JCP 1997. Controle da doença de Chagas. In JPC Dias, JR Coura (eds.). Clínica e terapêutica da doença de Chagas. Editora Fiocruz, Rio de Janeiro, p. 453-467.

Fagundes A, Marzochi MC, Fernandes O, Perez MA, Schubach AO, Schubach TM, Amendoeira MR, Mouta-Confort E, Marzochi KB 2007. First encounter of subclinical human Leishmania (Viannia) infection in state of Rio Grande do Sul, Brazil. Mem Inst Oswaldo Cruz 102: 1003-1005.

Fernandes CD, Murta SMF, Cerávolo IP, Krug LP, Vidigal PG, Stein- del M, Nardi N, Romanha AJ 1997. Characterization of Trypanosoma cruzi strains isolated from chronic patients, triatomines and opossums naturally infected from the state of Rio Grande do Sul, Brazil. Mem Inst Oswaldo Cruz 92: 343-351.

Fernandes CD, Tiecher FM, Fernandes DD, Pinheiro NM, Steindel M 1999. High rates of positive hemocultures in children and teenagers infected by Trypanosoma cruzi in the state of Rio Grande do Sul, Brazil. Mem Inst Oswaldo Cruz 94: 7-8.

Francolino SS, Antunes AF, Talice R, Rosa R, Selanikio J, de Rezende JM, Romanha AJ, Dias JC 2003. New evidence of spontaneous cure in human Chagas' disease. Rev Soc Bras Med Trop 36: $103-107$.

Galvão LMC, Cançado JR, Rezende DF, Krettli AU 1989. Hemoculture from chronic chagasic pasient using EDTA or heparin as anticoagulants. Braz J Med Biol Res 22: 841-843.

Gomes ML, Galvão LM, Macedo AM, Pena SD, Chiari E 1999. Chagas' disease diagnosis: comparative analysis of parasitologic, molecular and serologic methods. Am J Trop Med Hyg 60: 205-210.

Gutierrez R, Angulo VM, Tarazona Z, Britto C, Fernandes O 2004. Comparison of four serological tests for the diagnosis of Chagas disease in a Colombian endemic area. Parasitology 129: 439-444.

Lages-Silva E, Ramírez LE, Pedrosa AL, Crema E, da Cunha Galvão LM, Junho Pena SD, Macedo AM, Chiari E 2006. Variability of kinetoplast DNA gene signatures of Trypanosoma cruzi II strains from patients with different clinical forms of Chagas' disease in Brazil. J Clin Microbiol 44: 2167-2171.

Luquetti AO 1999. Evolution of knowledge on the etiological diagnosis of chagasic infection. Mem Inst Oswaldo Cruz 94: 283-284.

Luquetti AO, Miles MA, Rassi A, de Rezende JM, de Souza AA, Povoa MM, Rodrigues I 1986. Trypanosoma cruzi: zymodemes associated with acute and chronic Chagas disease in central Brazil. Trans R Soc Trop Med Hyg 80: 462-470.

Luquetti AO, Rassi A 2000. Diagnóstico laboratorial da infecção pelo Tripanossoma cruzi. In Z Brener, ZA Andrade, M Barral-Netto (eds). Trypanosoma cruzi e doença de Chagas, Guanabara Koogan, Rio de Janeiro, p. 344-378

Luz ZMP, Coutinho MG, Cançado JR 1993. Alta positividade de hemoculturas repetidas em pacientes chagásicos. Rev Soc Bras Med Trop 26: 66-67.

Marcon GEB, Andrade PD, Albuquerque DM, Wanderley JS, Almeida EA, Guariento ME, Costa SCB 2002. Use of a nested polymerase chain reaction (N-PCR) to detect Trypanosoma cruzi in blood samples from chronic chagasic patients and patients with doubtful serologies. Diagn Microbiol Infect Dis 43: 39-43.

Massad E 2007. The elimination of Chagas' disease from Brazil. Epidemiol Infect 4: 1-12.

Miles MA, Cedillos RA, Póvoa MM, de Souza AA, Prata A, Macedo V 1981. Do radically dissimilar Trypanosoma cruzi strains (zymodemes) cause Venezuelan and Brazilian forms of Chagas' disease? Lancet 1: 1338-1340.

Miles MA, Lanhan SM, De Souza AA, Povoa DG 1980. Further enzymic characters of Trypanosoma cruzi and their evaluation for strain identification. Trans R Soc Trop Med Hyg 74: 221-242.

Prata A 2001. Clinical and epidemiological aspects of Chagas disease. Lancet Infect Dis 1: 92-100.

Saldaña A, Sousa OE 1996. Trypanosoma rangeli and Trypanosoma cruzi: cross-reaction among their immunogenic components. Mem Inst Oswaldo Cruz 91: 81-82.

Silber AM, Bua J, Porcel BM, Segura EL, Ruiz AM 1997. Trypanosoma cruzi: specific detection of parasites by PCR in infected 
humans and vectors using a set of primers (BP1/BP2) targeted to a nuclear DNA sequence. Exp Parasitol 85: 225-232.

Silveira AC, Rezende DF 1994. Epidemiologia e controle da transmissão vetorial da doença de Chagas. Rev Soc Bras Med Trop 27: $11-22$.

Steindel M, Kramer Pacheco L, Scholl D, Soares M, de Moraes MH, Eger I, Kosmann C, Sincero TC, Stoco PH, Murta SM, de Carvalho-Pinto CJ, Grisard EC 2008. Characterization of Trypanosoma cruzi isolated from humans, vectors and animal reservoirs following an outbreak of acute human Chagas disease in Santa Catarina state, Brazil. Diag Microbiol Infect Dis 60: 25-32.
Sturm NR, Degrave W, Morel CM, Simpson L 1989. Sensitive detection and schizodeme classification of Trypanosoma cruzi cells by amplification of kinetoplast minicircles DNA sequences: use in diagnosis of Chagas disease. Mol Biochem Parasitol 33: 205-214.

Vinhaes MC, Dias JC 2000. Chagas disease in Brazil. Cad Saude Publica 16 (Suppl. 2): 7-12.

Yeo M, Acosta N, Llewellyn M, Sánchez H, Adamson S, Miles GA, López E, González N, Patterson JS, Gaunt MW, de Arias AR, Miles MA 2005. Origins of Chagas disease: Didelphis species are natural hosts of Trypanosoma cruzi I and armadillos hosts of Trypanosoma cruzi II, including hybrids. Int J Parasitol 35: 225-233. 